\title{
Recurrence of Cardiac Leiomyosarcoma After Three Months: A Case Study
}

\author{
Üç Ay Sonra Tekrarlayan Kardiyak Leiomyosarkom: Bir Vaka Çalışması
}

\section{Mihriban Yalcin ${ }^{1}$, Melih Urkmez ${ }^{1}$, Perihan Bilen ${ }^{2}$, Diyar Koprulu ${ }^{2}$}

${ }^{1}$ Department of Cardiovascular Surgery, Ordu State Hospital Ordu, Turkey

${ }^{2}$ Department of Cardiology, Ordu State Hospital, Ordu, Turkey

\section{ABSTRACT}

Leiomyosarcoma is an extremely rare mass of the heart. A 50 years-old female complained of palpitation and dyspnea was diagnosed as myxoma. The tumour is removed in an urgent operation and leiomyosarcoma was pathologicaly diagnosed. Post-operative CT scan revealed no metastases. Three months after the surgery, dyspnea and palpitation became resymptoms of her. Transthoracic and transesophageal echocardiography revealed a mobile left atrial mass. And she was reoperated 3 months after first operation. There was a mobile gelatinous mass in the left atrium stretching through to the mitral valve. The tumor was resected and mitral valve replaced.

Key Words: Cardiac tumor, leiomyosarcoma, myxoma

\section{ÖZET}

Leiomyosarkom kalbin son derece nadir görülen kitlelerindendir. 50 yaşında kadın hasta, çarpıntı ve dispne şikayeti ile başvurdu ve miksoma tanısı aldı. Obstrüktif semptomlar ve embolik riskler nedeniyle tümörü cerrahi olarak çıkardık ve patolojik olarak leiomyosarkom tanısı kondu. Ameliyat sonrası BT incelemesinde metastaz görülmedi. Ameliyattan üç ay sonra, hastanın yeniden dispne ve palpitasyon şikayetleri oldu. Transtorasik ve transözofageal ekokardiyografide mobil sol atriyal kitle saptandı. Ve hasta ilk ameliyattan 3 ay sonra yeniden açık kalp ameliyatı oldu. Sol atriyumda mitral kapağa hareketli jelatinimsi bir kitle vardı. Tümör rezeke edildi ve mitral kapak replasmanı yapıldı.

Anahtar Sözcükler: Kardiyak tümör, leiomyosarkom, mixoma

Geliş Tarihi: 09.11.2018

Kabul Tarihi:05.12.2018

\section{INTRODUCTION}

Primary cardiac tumors are rare, and most of them are benign. Myxoma is the most common benign cardiac tumor, and angiosarcoma is the most common malignant one. Leiomyosarcoma is a smooth muscle cell tumor and seen rarely. Leiomyosarcoma is a malignant mesenchymal tumor and originating from heart with an incidence of $0.001 \%$ to $0.03 \%$ (1) and $1 \%$ of all neoplasms. Here, we describe a 50 years-old female with repeating leiomyosarcoma admitted with increasing dyspnea 3 months after the first operation. Here, initial preoperative diagnosis was left atrial myxoma.

\section{CASE REPORT}

A 50 year-old female was admitted to cardiology department with shortness of breath (New York Heart Association class III-IV). The patient did not have personal history of cardiac disease. The patient was referred to us with a suspected diagnosis of left atial myxoma. Median sternotomy and aortobicaval cannulation were performed for excision of the left atrial mass. The mass was situated in the left atrium roof between the pulmonary veins. Intraoperative frozen section was performed and malignancy was suspected. The mass was removed as far as possible. 
An immunohistochemical stain was positive for smooth muscle actin and desmin, and negative for CD34, CD31, and S-100 protein. After histopathological and immunohistochemical exams, we concluded that the tumor was a grade II/III leiomyosarcoma. There was no evidence for another metastasis in positron emission tomography (PET)/CT. Then, the patient was referrred to oncology department, no chemotherapy recommended.

Three months after the operation, the patient returned with increasing dyspnea and was admitted with a recurrent tumor. An echocardiogram revealed a new hypoechoic and heterogeneous mass in the left atrium, which intermittently obstructed the mitral valve orifice.

Cardiopulmonary bypass was performed by aorto-bicaval cannulation. A mass was found in the posterior wall of the left atrium partially including the mitral valve. (Fig.1) The tumor was resected, and the underlying endocardium of the atrial wall was dissected from the heart; the mitral valve was replaced (Fig.2). The operation was done without complications. The pathological examination report of the mass was again leiomyosarcoma. We believed that the tumor had been completely removed, and in the early postoperative period there was no metastases. She was extubated 12 hours after surgery and was transferred to a general ward on the third post-operative day. She was referrred to oncology department again and this time chemotherapy was inititated with adriamycin and ifosfamide. The patient is now nine months out of the surgery and in a good condition with no recurrence or metastasis.

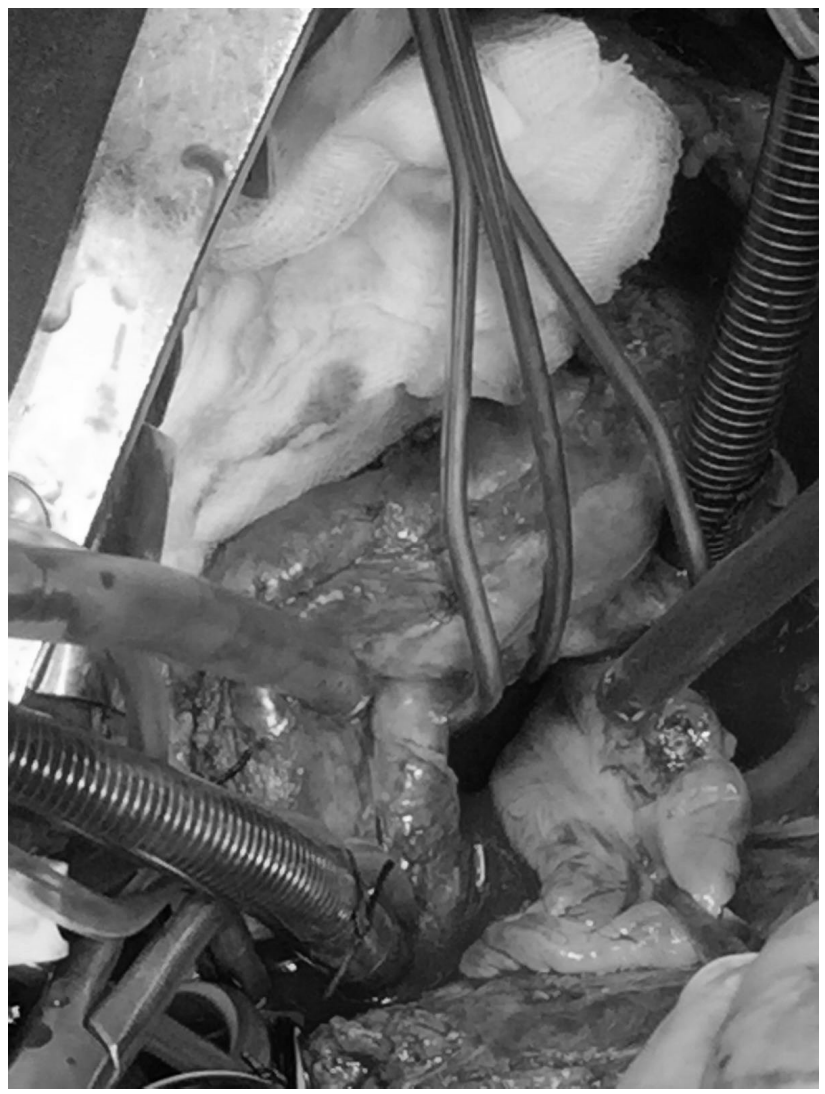

Figure 1: Intraoperative view of the tumor

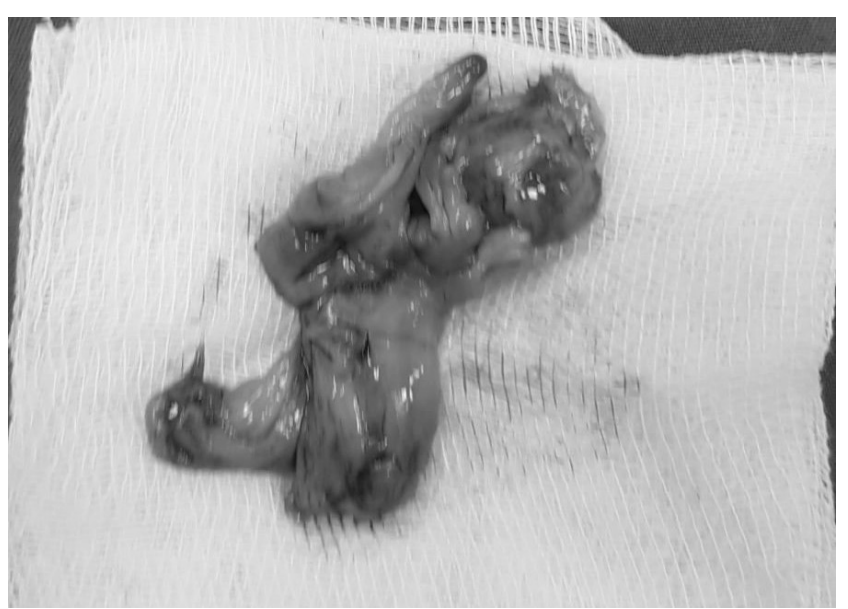

Figure 2: The existed Leiomyosarcoma

\section{DISCUSSION}

The incidence of primary cardiac tumors is $0.02 \%$. Of all cardiac tumors, only $20.6 \%$ of them are malignant; of these, only $0.025 \%$ are primary leiomyosarcomas (1). Dyspnea, chest pain, arrhythmia, and heart failure are the main symptoms of cardiac leiomyosarcoma. The standard methods for the diagnosis of leiomyosarcoma are transthoracic and transesophageal cardiac echocardiography and cardiac CT. The diagnosis is generally made intraoperatively or during the autopsy, and the median survival after diagnosis is 6 months (1).

The myocardium, mitral valve, pulmonary artery, left atrium, and pericardium are often included in cardiac sarcomas (2). The left atrium is the most common localization for leiomyosarcoma as in our case. The tumors usually have a broad, gelatinous base.

Indications for surgery for cardiac tumors arise from increased embolic risk, from hemodynamic disorders associated with tumor growth, and cardiac dysrhythmia. Metastases and local recurrence are common after removal, and thus the prognosis is poor (6 months after diagnosis)(1). The mean age of the patients with leiomyosarcoma is 45 , and the incidence is twice as high in women (1). Local recurrence and metastasis to the brain and lungs must be suspected after primary leiomyosarcoma.

Wang et all reported that the most common symptoms are the obstructive symptoms. The left atrium is the most common site, and surgery is the most common therapy in a study of 79 patients (3). This is especially true when it is located in the left atrium. The tumor may be misdiagnosed as cardiac myxoma by echocardiography $(4,5)$. In our case, myxoma was also the first diagnosis.

The findings for malignancy are immobile mass, pericardial effusion, broad base of the tumor, and neovascularity (4). Cardiac magnetic resonance imaging is recommended for additional structured and functional assessment of most reported misdiagnosis (5).

\section{CONCLUSION}

Surgical resection combined with chemotherapy is the basic treatment for cardiac leiomyosarcoma. The effect of radiotherapy is restricted because of low sensitivity and myocardium damage. In our case, there were no metastases, and initially the oncologists decided to follow the patient without chemotherapy but after the recurrence in a short time, they started chemotherapy.

\section{Conflict of interest}

No conflict of interest was declared by the authors.

\section{REFERENCES}

1. Butany J, Nair V, Naseemuddin A, Nair GM, Catton C, Yau T. Cardiac tumors: Diagnosis and management. Lancet Oncol 2005; 6: 219- 28.

2. Suzuki R, Miyamoto T, Hirayama R, Sakaguchi T, Uekihara K, Yoshioka Y. Primary cardiac leiomyosarcoma causing severe pulmonary hypertension. Journal of Cardiac Surgery 2017; 32:794-6.

3. Wang JG, Cui L, Jiang T, Li YJ, Wei ZM..Primary cardiac leiomyosarcoma: An analysis of clinical characteristics and outcome patterns. Asian Cardiovasc Thorac Ann. 2015; 23: 623-30.

4. Mazzola A, Spano JP, Valente M, Gregorini R, Villani C, Di Eusanio M, et al. Leiomyosarcoma of the left atrium mimicking a left atrial myxoma. J Thorac Cardiovasc Surg 2006; 131: 224-6.

5. Ann SH, Jung SY, Yi JE, Chin JY, Kim TS, Jung HO, et al. A primary left atrial leiomyosarcoma mimicking myxoma: echocardiographic findings. Echocardiography 2012;29: E226-9. 